\title{
The regulation of fatty acid biosynthesis in some estuarine strains of Flexibacter
}

\author{
Pablo Intriago* \\ School of Ocean Sciences, Marine Science Laboratories, Menai Bridge, Gwynedd LL59 5EY, UK
}

(Received 25 January 1991; revised 13 September 1991; accepted 3 October 1991)

\begin{abstract}
The mechanism of unsaturated fatty acid biosynthesis in two estuarine strains of Flexibacter was investigated. Addition of cyclic AMP (cAMP) inhibited the incorporation of radiolabelled acetate into fatty acids of lateexponential phase cultures of strain Inp2. Cerulenin selectively inhibited the incorporation of radioactive acetate into the major fatty acid, 16:1. When Flexibacter strain Inp3 was grown in a medium of high osmotic strength, polyunsaturated fatty acids were present, but they were absent from cultures grown in media with an osmotic strength close to that of sea water. Addition of cAMP to cultures growing at high osmotic strength suppressed the formation of polyunsaturated fatty acids; the uncoupler 2,4-dinitrophenol had a similar effect. The findings are discussed in the context of the suggestion made by Intriago and Floodgate (Journal of General Microbiology 137, 1503-1509, 1991) that Flexibacter strains possess both the anaerobic and aerobic pathways for unsaturated fatty acid biosynthesis, the activity of the latter being modulated by the intracellular concentration of cAMP.
\end{abstract}

\section{Introduction}

Only two biochemical mechanisms are recognized for the introduction of a double bond into a fatty acid. In the anaerobic pathway, which can be considered part of the fatty acid synthetase system, a double bond is formed when the chain generally has 10 or 12 carbon atoms. The chain is then lengthened to produce eventually either C16:1w7 or C16:1w9 respectively (Goldfine \& Bloch, 1961; Erwin \& Bloch, 1964; Fulco, 1983). This pathway is found in all anaerobes, facultative anaerobes and some aerobic bacteria (Harwood \& Russell, 1984; Schweizer, 1989). In contrast, the aerobic or oxygen-dependent pathway introduces double bonds by desaturation of existing chains, usually 16 or 18 carbon atoms in length. This latter pathway is found in some aerobic bacteria, especially Gram-positive ones, as well as non-parasitic eukaryotes (Fulco, 1970; Schweizer, 1989). The position of the first double bond in plants and microbes is usually at the 9,10 position (Bloomfield \& Bloch, 1960; Russell, 1978). Scheuerbrandt \& Bloch (1962) suggested that the

\footnotetext{
- Present address: Aqualab, PO Box 09-01-5738, Guayaquil, Ecuador. Fax 4284409.

Abbreviations: DNP, 2,4-dinitrophenol; UFA, unsaturated fatty acid; PUFA, polyunsaturated fatty acid; p.p.t., parts per thousand (salinity).
}

anaerobic and the aerobic pathways were mutually exclusive. However, Wada et al. (1989) have recently demonstrated the presence of both pathways in a psychrotrophic Pseudomonas.

The presence of polyunsaturated fatty acids (PUFAs) in marine bacteria has been demonstrated (Delong \& Yayanos, 1986; Wirsen et al., 1987; Yazawa et al., 1988; Intriago \& Floodgate, 1991), but the mechanism controlling their biosynthesis is unknown. A potential regulator such as cyclic AMP (cAMP) is known to affect cell metabolism in different ways, including regulation of gene expression (Pauli et al., 1974), control of cellular morphogenesis (Larsen \& Sypherd, 1974) and phosphorylation of proteins (Saha et al., 1988). In contrast, there are few reports in the literature about the effect of cAMP on fatty acid composition. Dallas et al. (1976) showed that the fatty acid composition of Escherichia coli was regulated by cAMP and Alaniz et al. (1976) found that incubation of cultured mouse cells with cAMP decreases the desaturation of linolenic acid.

Cerulenin was used in the present study because it is known to reduce fatty acid synthesis in $E$. coli by inhibiting $\beta$-ketoacyl-ACP synthase (D'Agnolo et al., 1973). Butkke \& Ingram (1978) suggested that $\beta$ ketoacyl-ACP synthase I, which elongates cis-decenoyl$\mathrm{ACP}$ to $\mathrm{Cl6}: 1 \mathrm{w} 7$ in $E$. coli, is more sensitive to cerulenin than is $\beta$-ketoacyl-ACP synthase II, which elongates $\mathrm{C} 16: 1$ to $\mathrm{C} 18: 1$. Thus, inhibition of unsaturated fatty 
acid (UFA) synthesis by cerulenin can be considered as an inhibition of the anaerobic pathway.

The rationale of this study was to examine the effect of cAMP, cerulenin and high osmotic strength on the incorporation of radioactive acetate into exponentially growing cultures of Flexibacter strain Inp2, a PUFAcontaining strain, and to compare their effects on the fatty acid composition of Flexibacter strain Inp3, which is deficient in PUFAs.

\section{Methods}

Culture conditions. The Flexibacter strains Inp2 and Inp3 used in this study were isolated after continuous cultivation of the wild-type Flexibacter strain Inp on high salinity medium (Intriago \& Floodgate, 1991). Besides the differences in fatty acid composition, no nutritional, physiological or morphological differences between the strains were found. The culture conditions were as described by Intriago \& Floodgate (1991). The carbon source was $12 \%(\mathrm{w} / \mathrm{v})$ sucrose, $0.5 \%$ $(w / v)$ glucose or $0.5 \%(w / v)$ soluble starch. Salinity was increased by adding the artificial sea-water salts formulated by Reichenbach \& Dworkin (1981). The doubling time of all strains in each of the media was $12 \mathrm{~h}$. When the cultures reached exponential phase (about $40 \mathrm{~h}$ ), sodium $\left[1^{-14} \mathrm{C}\right]$ acetate [Amersham; specific radioactivity $50-60 \mathrm{mCi}$ $\left.\mathrm{mol}^{-1}\left(1.85-2.22 \mathrm{GBq} \mathrm{mol}^{-1}\right)\right]$ was added to the medium to give a final concentration of $\left.1.0 \mu \mathrm{Ci} \mathrm{ml}^{-1}(37 \mathrm{kBq} \mathrm{ml})^{-1}\right)$ and incubated for $4 \mathrm{~h}$ before harvesting the bacteria.

When either cAMP (1 mM, Aldrich) or cerulenin ( $5 \mu \mathrm{g} \mathrm{ml}^{-1}$, Sigma) were included in the incubation mixtures for Inp2, they were added at the same time as the radioisotope.

When cAMP (1 mM) or the uncoupler 2,4-dinitrophenol (DNP; $1 \mu \mathrm{M} ; \mathrm{BDH})$ were added to the culture medium of Inp3 they were sterilized by filtration and added to the growth medium at the beginning of the experiment.

Lipid extraction. Bacteria were harvested as described in Intriago \& Floodgate (1991). Lipids were extracted by the method of Bligh \& Dyer (1959), saponified with $2 \mathrm{ml} 5 \%(\mathrm{w} / \mathrm{v}) \mathrm{KOH}$ in $50 \%(\mathrm{v} / \mathrm{v})$ methanol in water for $1 \mathrm{~h}$ at $100{ }^{\circ} \mathrm{C}$, cooled and acidified with $6 \mathrm{M}-\mathrm{HCl}$. The fatty acids were extracted twice with $1 \mathrm{ml}$ chloroform and dried under nitrogen.

Gas-liquid chromatographic analysis. Fatty acids of Inp3 were methylated and analysed as described in Intriago \& Floodgate (1991).

Radio-HPLC analysis. Fatty acids of Inp2 were derivatized using a technique adapted from that of Lam \& Gruska (1985). Derivatization was started by adding $20 \mu \mathrm{l} 5 \%(\mathrm{w} / \mathrm{v}) \mathrm{KOH}$ in $50 \%(\mathrm{v} / \mathrm{v})$ methanol in water to the dried lipid sample, and then evaporating the methanol and water using a stream of nitrogen gas. The fatty acid potassium salts so formed were dissolved in $1 \mathrm{ml}$ acetonitrile, plus $150 \mu \mathrm{l} p$-bromophenacyl bromide (Sigma) $\left(50 \mathrm{mg} \mathrm{ml}^{-1}\right)$ and $150 \mu \mathrm{l} 18$ crown 6 (dicyclohexano-18-crown-6) (Aldrich) $\left(5 \mathrm{mg} \mathrm{m}^{-1}\right)$ dissolved in acetonitrile. The reaction mixture was heated for $25 \mathrm{~min}$ at $85^{\circ} \mathrm{C}$. Excess reagent after derivatization was eliminated by adding $2 \mathrm{ml}$ water and $2 \mathrm{ml}$ hexane to the reaction vial and mixing vigorously. The hexane layer was removed and placed in a second vial and evaporated using nitrogen gas. The fatty acid methyl esters were redissolved in $100 \mu \mathrm{l}$ acetonitrile, and $10 \mu \mathrm{l}$ was injected into a Varian 2050 HPLC, fitted with a C18 ODS $23 \mu$ $150 \mathrm{~cm} \times 4.6 \mathrm{~mm}$ column (Spherisorb, Alltech). An isocratic programme with acetonitrile/water $(85: 15, \mathrm{v} / \mathrm{v})$ as mobile phase was used, with a flow rate of $1.5 \mathrm{ml} \mathrm{min}^{-1}$ equivalent to $120 \mathrm{bar}$, and was monitored at a wavelength of $254 \mathrm{~nm}$. The radioactive detector was a
Berthold HPLC radioactivity monitor (LB506C-1), connected to a Compaq-Desk PRO 386/20 computer. A typical run time was 30 min. Identification of peaks was based on comparison with pure standards, and compared against gas-liquid chromatographic analyses.

The mobile phase used, acetonitrile/water $(85: 15, \mathrm{v} / \mathrm{v})$, did not completely resolve $\mathrm{C} 16: 0$ from $\mathrm{C} 18: 1$, and they were reported together, but this did not affect the aims of this study.

It is relevant to point out that whereas fatty acid analysis by gasliquid chromatography agrees more closely with weight percentages, the values of fatty acid phenacyl derivatives quantified by HPLC are closer to mole percentages (Wood \& Lee, 1983).

\section{Results}

\section{Fatty acid biosynthesis in Flexibacter strain Inp2}

The fatty acid composition of Flexibacter strain Inp2 was broadly similar whether it was grown in $12 \%$ sucrose or $0.5 \%$ glucose (cf. Tables 1 and 2). Both $\mathrm{C} 18: 2$ and $\mathrm{C} 18: 3$

Table 1. Percentage fatty acid composition and distribution of radioactivity among fatty acids in Flexibacter strain Inp2 after growth on $12 \%$ sucrose

Values represent two separate experiments, after correcting for quenching and background.

\begin{tabular}{lcc}
\hline \hline $\begin{array}{l}\text { Fatty } \\
\text { acid }\end{array}$ & $\begin{array}{l}\text { Composition } \\
\text { by mass (\%) }\end{array}$ & Radioactivity (\%) \\
\hline $14: 0$ & $3 \cdot 5-1 \cdot 7$ & $3 \cdot 9-5 \cdot 9$ \\
$14: 1$ & $4 \cdot 8-1 \cdot 2$ & $4 \cdot 0-4 \cdot 5$ \\
i15:0 & $4 \cdot 6-5 \cdot 1$ & $0 \cdot 0-0 \cdot 0$ \\
a15:0 & $5 \cdot 3-5 \cdot 0$ & $0 \cdot 0-0 \cdot 0$ \\
$15: 0$ & $0 \cdot 0-0 \cdot 0$ & $0 \cdot 0-0 \cdot 0$ \\
$16: 0 / 18: 1$ & $8 \cdot 1-7 \cdot 8$ & $25 \cdot 2-32 \cdot 2$ \\
$16: 1$ & $61 \cdot 5-57 \cdot 2$ & $53 \cdot 5-54 \cdot 2$ \\
$18: 2$ & $8 \cdot 7-7 \cdot 3$ & $8 \cdot 0-3 \cdot 1$ \\
$18: 3$ & $3 \cdot 0-3 \cdot 8$ & $3 \cdot 2-0 \cdot 0$ \\
Unknown & $0 \cdot 6-0 \cdot 4$ & $0 \cdot 0-0 \cdot 0$ \\
& & Total c.p.m. $12280-33210$ \\
\hline \hline
\end{tabular}

Table 2. Percentage fatty acid composition and distribution of radioactivity among fatty acids in Flexibacter strain Inp2 after growth on $0.5 \%$ glucose

Values represent two separate experiments, after correcting for quenching and background.

\begin{tabular}{lcc}
\hline \hline $\begin{array}{l}\text { Fatty } \\
\text { acid }\end{array}$ & $\begin{array}{l}\text { Composition } \\
\text { by mass (\%) }\end{array}$ & Radioactivity (\%) \\
\hline $14: 0$ & $3 \cdot 1-2 \cdot 8$ & $4 \cdot 9-2 \cdot 3$ \\
$14: 1$ & $7 \cdot 0-11 \cdot 1$ & $0 \cdot 0-0 \cdot 0$ \\
i15:0 & $4 \cdot 4-7 \cdot 2$ & $0 \cdot 0-0 \cdot 0$ \\
a15:0 & $8 \cdot 1-0 \cdot 0$ & $0 \cdot 0-0 \cdot 0$ \\
$15: 0$ & $0 \cdot 0-0 \cdot 0$ & $0 \cdot 0-0 \cdot 0$ \\
$16: 0 / 18: 1$ & $8 \cdot 1-13 \cdot 0$ & $34 \cdot 5-56 \cdot 4$ \\
$16: 1$ & $56 \cdot 8-55 \cdot 5$ & $54 \cdot 8-41 \cdot 2$ \\
$18: 2$ & $7 \cdot 3-6 \cdot 9$ & $0 \cdot 0-0 \cdot 0$ \\
$18: 3$ & $3 \cdot 4-0 \cdot 0$ & $0 \cdot 0-0 \cdot 0$ \\
Unknown & $1 \cdot 1-3 \cdot 2$ & $0 \cdot 0-0 \cdot 0$ \\
& & Total c.p.m. 9940-14060 \\
\hline \hline
\end{tabular}


Table 3. Effect of CAMP on fatty acid composition and distribution of radioactivity among fatty acids in Flexibacter strain Inp2 after growth on $12 \%$ sucrose

Values represent two separate experiments, after correcting for quenching and background. cAMP (1 mM) was added together with the radioactive precursor $4 \mathrm{~h}$ before harvesting the bacteria.

\begin{tabular}{lcc}
\hline \hline $\begin{array}{l}\text { Fatty } \\
\text { acid }\end{array}$ & $\begin{array}{c}\text { Composition } \\
\text { by mass }(\%)\end{array}$ & \multicolumn{1}{c}{ Radioactivity (\%) } \\
\hline $14: 0$ & $2 \cdot 4-3 \cdot 6$ & $36 \cdot 5-20 \cdot 9$ \\
$14: 1$ & $4 \cdot 3-6 \cdot 4$ & $0 \cdot 0-0 \cdot 0$ \\
i15:0 & $2 \cdot 3-4 \cdot 6$ & $0 \cdot 0-0 \cdot 0$ \\
a15:0 & $4 \cdot 5-6 \cdot 4$ & $0 \cdot 0-0 \cdot 0$ \\
$15: 0$ & $0 \cdot 0-0 \cdot 0$ & $0 \cdot 0-0 \cdot 0$ \\
$16: 0 / 18: 1$ & $35 \cdot 7-9 \cdot 4$ & $48 \cdot 1-36 \cdot 0$ \\
$16: 1$ & $36 \cdot 4-57 \cdot 5$ & $14 \cdot 2-37 \cdot 3$ \\
$18: 2$ & $12 \cdot 4-7 \cdot 2$ & $0 \cdot 0-0 \cdot 0$ \\
$18: 3$ & $0 \cdot 0-2 \cdot 8$ & $0 \cdot 0-0 \cdot 0$ \\
Unknown & $1 \cdot 0-2 \cdot 4$ & $0 \cdot 0-0 \cdot 0$ \\
& & Total c.p.m. $12400-15300$ \\
\hline \hline
\end{tabular}

Table 4. Effect of cerulenin on fatty acid composition and distribution of radioactivity among fatty acids in Flexibacter strain Inp2 after growth on $12 \%$ sucrose

Values represent two separate experiments, after correcting for quenching and background. Cerulenin $\left(5 \mu \mathrm{g} \mathrm{ml}^{-1}\right)$ was added together with the radioactive precursor $4 \mathrm{~h}$ before harvesting the bacteria.

\begin{tabular}{lcc}
\hline \hline $\begin{array}{l}\text { Fatty } \\
\text { acid }\end{array}$ & $\begin{array}{l}\text { Composition } \\
\text { by mass (\%) }\end{array}$ & Radioactivity (\%) \\
\hline $14: 0$ & $2 \cdot 7-3 \cdot 3$ & $0 \cdot 0-0 \cdot 0$ \\
$14: 1$ & $10 \cdot 9-7 \cdot 3$ & $0 \cdot 0-0 \cdot 0$ \\
i15:0 & $5 \cdot 1-4 \cdot 7$ & $0 \cdot 0-0 \cdot 0$ \\
a15:0 & $9 \cdot 4-7 \cdot 0$ & $0 \cdot 0-0 \cdot 0$ \\
$15: 0$ & $0 \cdot 0-0 \cdot 0$ & $0 \cdot 0-0 \cdot 0$ \\
$16: 0 / 18: 1$ & $8 \cdot 1-11 \cdot 9$ & $100 \cdot 0-100 \cdot 0$ \\
$16: 1$ & $54 \cdot 4-54 \cdot 6$ & $0 \cdot 0-0 \cdot 0$ \\
$18: 2$ & $4 \cdot 0-4 \cdot 6$ & $0 \cdot 0-0 \cdot 0$ \\
$18: 3$ & $2 \cdot 9-3 \cdot 1$ & $0 \cdot 0-0 \cdot 0$ \\
Unknown & $2 \cdot 7-1 \cdot 8$ & $0 \cdot 0-0 \cdot 0$ \\
& & Total c.p.m. $1960-640$ \\
\hline \hline
\end{tabular}

were present in bacteria grown in either medium. However, none of the radiolabelled acetate appeared in these acids in glucose-grown cells after incubation with the precursor for $4 \mathrm{~h}$, whereas a significant amount of radioactivity was incorporated into these acids in sucrose-grown cultures (Tables 1 and 2).

Addition of cAMP to the sucrose medium did not affect bacterial growth, but prevented the biosynthesis of PUFAs. The relative percentages of radiolabelled material incorporated from acetate into myristic and palmitic/oleic acids were increased compared with the control whilst the incorporation into palmitoleic/oleic acids was decreased (cf. Tables 1 and 3 ).
Table 5. Effect of cerulenin on fatty acid composition and distribution of radioactivity among fatty acids in Flexibacter strain Inp2 after growth on $0.5 \%$ glucose

Values represent two separate experiments, after correcting for quenching and background. Cerulenin $\left(5 \mu \mathrm{g} \mathrm{ml}^{-1}\right)$ was added together with the radioactive precursor $4 \mathrm{~h}$ before harvesting the bacteria.

\begin{tabular}{lcc}
\hline \hline $\begin{array}{l}\text { Fatty } \\
\text { acid }\end{array}$ & $\begin{array}{l}\text { Composition } \\
\text { by mass (\%) }\end{array}$ & Radioactivity (\%) \\
\hline $14: 0$ & $3 \cdot 5-2 \cdot 1$ & $26 \cdot 5-11 \cdot 6$ \\
$14: 1$ & $8 \cdot 8-3 \cdot 7$ & $1 \cdot 7-1 \cdot 0$ \\
i15:0 & $5 \cdot 8-2 \cdot 1$ & $8 \cdot 9-2 \cdot 8$ \\
a $15: 0$ & $0 \cdot 0-4 \cdot 0$ & $0 \cdot 0-0 \cdot 0$ \\
$15: 0$ & $0 \cdot 0-0 \cdot 3$ & $0 \cdot 0-1 \cdot 8$ \\
$16: 0 / 18: 1$ & $31 \cdot 7-32 \cdot 6$ & $43 \cdot 9-49 \cdot 0$ \\
$16: 1$ & $34 \cdot 4-41 \cdot 5$ & $16 \cdot 0-21 \cdot 8$ \\
$18: 2$ & $13 \cdot 1-10 \cdot 6$ & $2 \cdot 0-7 \cdot 9$ \\
$18: 3$ & $0 \cdot 0-1 \cdot 3$ & $0 \cdot 0-2 \cdot 6$ \\
Unknown & $2 \cdot 6-1 \cdot 7$ & $0 \cdot 0-0 \cdot 0$ \\
& & Total c.p.m. \\
\hline \hline
\end{tabular}

Addition of cerulenin to the sucrose medium resulted in a marked decrease of fatty acid synthesis; radiolabelled acetate was incorporated only into the palmitic/ oleic acids fraction (Table 4). Cerulenin had a different effect on cultures grown in glucose medium (cf. Tables 4 and 5). In contrast to bacteria grown in $12 \%$ sucrose, incorporation of radioactive acetate into $\mathrm{C} 16: 1$ and total fatty acids was only partly inhibited, and the precursor was readily incorporated into both PUFAs (Table 5).

\section{Effect of osmotic strength on Flexibacter strain Inp3}

A comparison of the fatty acid composition of Flexibacter strain Inp3 cultured in glucose medium (Table 6) with that of strain Inp, described in Intriago \& Floodgate (1991), under the same conditions highlights the dissimilarities between these two strains: whereas PUFAs were practically absent in Inp3, they represented up to $20 \%$ of the total fatty acids in Inp. However, the data in Table 6 illustrates that synthesis of PUFAs was restored once Inp3 was grown in a high osmotic strength medium such as $12 \%$ sucrose or starch-Inp medium at 60 p.p.t. salinity.

Table 7 shows the fatty acid composition of Inp3 cultured in five different experiments, with starch-Inp containing betaine as basic medium, and four individually added salts, at the concentrations given for the artificial sea-water mixture described by Reichenbach \& Dworkin (1981). In another experiment $30 \mathrm{~g} \mathrm{KCl}^{-1}$ (approximately $0.4 \mathrm{M}$, final concentration) was added to the medium to compare the effects of equal weight concentrations of $\mathrm{NaCl}$ and $\mathrm{KCl}$. Addition of $\mathrm{NaCl}$ alone led to PUFA levels similar to those obtained with 
Table 6. Fatty acid composition of Flexibacter strain Inp3 after growth on different media

Values in parentheses represent means \pm 1 SD from two separate experiments. ND, Not detected.

\begin{tabular}{|c|c|c|c|c|c|c|c|}
\hline \multirow[b]{2}{*}{$\begin{array}{l}\text { Fatty } \\
\text { acid }\end{array}$} & \multicolumn{7}{|c|}{ Fatty acid composition (percentage of total fatty acids) } \\
\hline & $\begin{array}{l}\text { Glucose } \\
\left(5 \mathrm{gl}^{-1}\right)\end{array}$ & $\begin{array}{c}\text { Starch } \\
\left(5 \mathrm{~g} \mathrm{I}^{-1}\right)\end{array}$ & $\begin{array}{c}\text { Sucrose } \\
(12 \%)\end{array}$ & $\begin{array}{l}\text { Sucrose }(12 \%) \\
+1 \text { mM-cAMP }\end{array}$ & $\begin{array}{l}\text { Starch } \\
\text { (60 p.p.t.) }\end{array}$ & $\begin{array}{l}\text { Starch (60 p.p.t.) } \\
+1 \text { mM-cAMP }\end{array}$ & $\begin{array}{l}\text { Starch (60 p.p.t.) } \\
\quad+1 \mu \mathrm{M}-\mathrm{DNP}\end{array}$ \\
\hline $14: 0$ & ND & $2 \cdot 1(0 \cdot 2)$ & $1 \cdot 3(0 \cdot 6)$ & $1 \cdot 8(0 \cdot 3)$ & $2 \cdot 2(0 \cdot 6)$ & $1.9(0 \cdot 2)$ & $2 \cdot 3(0 \cdot 4)$ \\
\hline i1 $5: 1$ & $4 \cdot 3(0 \cdot 6)$ & $7 \cdot 9(1 \cdot 0)$ & $1 \cdot 6(0 \cdot 3)$ & $4 \cdot 4(0 \cdot 1)$ & $2 \cdot 0(0 \cdot 3)$ & $6 \cdot 3(0 \cdot 1)$ & $5 \cdot 3(1 \cdot 1)$ \\
\hline a15:0 & $0 \cdot 2(0 \cdot 1)$ & $0.8(0.2)$ & $0 \cdot 2(0 \cdot 1)$ & $0.4(0.3)$ & $0.5(0.2)$ & $0 \cdot 3(0 \cdot 4)$ & $0.9(0 \cdot 3)$ \\
\hline $15: 0$ & $0.4(0 \cdot 2)$ & $0.4(0.6)$ & $0 \cdot 4(0 \cdot 2)$ & $0.8(0 \cdot 5)$ & $0 \cdot 8(0 \cdot 3)$ & $0 \cdot 5(0 \cdot 7)$ & $0 \cdot 7(0 \cdot 1)$ \\
\hline $16: 0$ & $25 \cdot 0(1 \cdot 2)$ & $23 \cdot 1(0 \cdot 8)$ & $28 \cdot 4(0 \cdot 0)$ & $23 \cdot 3(4 \cdot 3)$ & $28 \cdot 5(0 \cdot 4)$ & $21 \cdot 3(4 \cdot 6)$ & $17 \cdot 8(1 \cdot 1)$ \\
\hline $16: 1 \omega 9$ & ND & ND & $0.5(0 \cdot 2)$ & $0 \cdot 2(0 \cdot 3)$ & $2 \cdot 4(0.4)$ & ND & ND \\
\hline $16: 1 \omega 7$ & $1 \cdot 0(0 \cdot 3)$ & $2 \cdot 5(0.0)$ & $1 \cdot 2(0.2)$ & $1 \cdot 6(0.6)$ & $2 \cdot 1(0 \cdot 1)$ & $3 \cdot 0(1 \cdot 3)$ & $2 \cdot 8(0 \cdot 6)$ \\
\hline $16: 1 \omega 5$ & $60 \cdot 8(0 \cdot 2)$ & $57 \cdot 9(0 \cdot 1)$ & $13 \cdot 3(1 \cdot 5)$ & $43.5(2.4)$ & $22 \cdot 1(4 \cdot 7)$ & $45 \cdot 6(11 \cdot 4)$ & $59 \cdot 3(0 \cdot 5)$ \\
\hline $18: 0$ & $1 \cdot 3(0 \cdot 9)$ & $0 \cdot 6(0 \cdot 3)$ & $4 \cdot 1(1 \cdot 0)$ & $2 \cdot 4(0.4)$ & $4 \cdot 7(0 \cdot 3)$ & $4 \cdot 9(1 \cdot 1)$ & $3.6(3.4)$ \\
\hline $18: 1 \omega 9$ & $0.8(0.3)$ & $0.9(0.0)$ & $10 \cdot 0(1 \cdot 1)$ & $5 \cdot 2(2 \cdot 1)$ & $6.8(0.7)$ & $6 \cdot 8(4 \cdot 7)$ & $1 \cdot 5(0 \cdot 1)$ \\
\hline $18: 1 \omega 7$ & $0 \cdot 2(0 \cdot 1)$ & $0 \cdot 1(0 \cdot 1)$ & $2 \cdot 2(0 \cdot 3)$ & $1 \cdot 2(0 \cdot 7)$ & $5 \cdot 8(1 \cdot 1)$ & $2 \cdot 2(3 \cdot 1)$ & $0.3(0 \cdot 1)$ \\
\hline $18: 2 \omega 6$ & $0.2(0.0)$ & $0.2(0 \cdot 1)$ & $9.8(0.8)$ & $2 \cdot 3(0 \cdot 9)$ & $6 \cdot 1(0 \cdot 9)$ & $2.9(0.9)$ & $0.9(0.5)$ \\
\hline $18: 3 \omega 3$ & ND & ND & $1.0(0.2)$ & $0.6(0.4)$ & $2 \cdot 0(0.2)$ & $0.7(0.0)$ & $0 \cdot 3(0 \cdot 2)$ \\
\hline $20: 1 \omega 9$ & ND & ND & $2 \cdot 1(0.8)$ & ND & ND & ND & ND \\
\hline Unknown & ND & ND & $10 \cdot 2(2 \cdot 5)$ & ND & ND & ND & ND \\
\hline
\end{tabular}

Table 7. Fatty acid composition of Flexibacter strain Inp3 after growth on starch-Inp medium plus salts

Flexibacter strain Inp3 was grown on starch-Inp medium containing $10 \mathrm{~mm}$-betaine together with individually added salts at concentrations corresponding to those in the artificial sea-water mixture described in Methods. ND, Not detected.

\begin{tabular}{lccccc}
\hline \multicolumn{5}{c}{ Fatty acid composition (percentage of total fatty acids) } \\
\cline { 2 - 6 } Fatty & $\mathrm{NaCl}$ & $\mathrm{KCl}$ & $\begin{array}{c}\mathrm{MgSO}_{4} / \\
\mathrm{MgCl}_{2}\end{array}$ & $\mathrm{CaCl}_{2}$ & $\mathrm{KCl}$ \\
acid & $\left(30 \mathrm{~g} \mathrm{I}^{-1}\right)$ & $\left(0.7 \mathrm{~g} \mathrm{l}^{-1}\right)$ & $\left(11.2 \mathrm{~g} \mathrm{I}^{-1}\right)$ & $\left(1.0 \mathrm{~g} \mathrm{I}^{-1}\right)$ & $\left(30 \mathrm{~g} \mathrm{I}^{-1}\right)$ \\
\hline $14: 0$ & 1.2 & 0.6 & 1.1 & 1.7 & 1.5 \\
$115: 0$ & 0.9 & 6.5 & 5.0 & 6.9 & 4.1 \\
a15:0 & ND & 0.6 & $\mathrm{ND}$ & $\mathrm{ND}$ & 0.1 \\
$15: 0$ & $\mathrm{ND}$ & $\mathrm{ND}$ & $\mathrm{ND}$ & $\mathrm{ND}$ & 0.2 \\
$16: 0$ & 39.0 & 21.7 & 21.3 & 19.9 & 14.9 \\
$16: 1 \omega 9$ & $\mathrm{ND}$ & $\mathrm{ND}$ & $\mathrm{ND}$ & $\mathrm{ND}$ & 0.7 \\
$16: 1 \omega 7$ & $\mathrm{ND}$ & 2.3 & 1.4 & 1.5 & 0.4 \\
$16: 1 \omega 5$ & 18.0 & 62.6 & 59.4 & 55.7 & 61.4 \\
$18: 0$ & 25.2 & 1.3 & 2.8 & 2.4 & 1.5 \\
$18: 1 \omega 9$ & 5.8 & 0.5 & 1.9 & 2.7 & 5.2 \\
$18: 1 \omega 7$ & ND & ND & ND & 0.3 & 0.8 \\
$18: 2 \omega 6$ & 6.1 & 0.4 & 2.2 & 1.4 & 1.0 \\
$18: 3 \omega 3$ & 1.8 & ND & ND & 0.6 & 0.4 \\
\hline \hline
\end{tabular}

the full artificial sea-water complex. Both $\mathrm{MgSO}_{4} / \mathrm{MgCl}_{2}$ and $\mathrm{CaCl}_{2}$ slightly increased the PUFA content, whears no change was found when $\mathrm{KCl}$ was added at either concentration.

\section{Effect of cAMP and DNP on Flexibacter strain Inp3}

Addition of cAMP to the culture medium lowered the proportion of PUFAs in Flexibacter strain Inp3 growing at a high salt concentration in $12 \%$ sucrose medium
(Table 6). Addition of cAMP reduced the proportion of all acids with an 18-carbon chain length in Inp3. The effects of the uncoupler DNP $(1 \mu \mathrm{M})$ and cAMP on the fatty acid composition of Inp3 were similar (Table 6). Although DNP did not prevent the growth of Inp3 it reduced the growth rate approximately twofold.

\section{Discussion}

Intriago \& Floodgate (1991) regarded the presence and inverse relationship in Flexibacter strain Inp between the two major fatty acids $\mathrm{C} 16: 1 \mathrm{w} 5$ and $\mathrm{C} 18: 1 \mathrm{w} 9$ as evidence for the presence of both the aerobic and anaerobic pathways for synthesis of unsaturated fatty acids in this bacterium. If the anaerobic pathway were present the antibiotic cerulenin should inhibit synthesis by this pathway. Fatty acid metabolism in Flexibacter strain Inp2 was affected by cerulenin in two ways: firstly, cerulenin inhibited fatty acid synthetase, and with it the synthesis of $\mathrm{C16}: 1$; secondly, it enhanced PUFA synthesis. These two effects could be the result of the presence of both the aerobic and anaerobic pathways for UFA synthesis. It also shows that as the flow of substrate from one pathway rises, the flow of substrate from the other is lowered. Wada et al. (1989) demonstrated the presence of both pathways for fatty acid synthesis in Pseudomonas E-3. The selectivity of cerulenin to inhibit UFA synthesis by the anaerobic pathway, is well documented (Buttke \& Ingram, 1978; Wada et al., 1989). The partial inhibition of $\mathrm{C} 16: 1$ synthesis by cerulenin in glucose medium may be due to either a more resistant $\beta$-keto-acyl synthase I present in bacteria grown in 
glucose, or the palmitoleate detected was an isomer other than $\mathrm{C16}: 1 \mathrm{w} 5$, and was synthesized by the aerobic pathway.

The results of Intriago \& Floodgate (1991), together with these from the present study, show that high osmotic strength stimulates PUFA production in Flexibacter Inp and related strains, and that this is prevented by addition of cAMP to the medium. Piovanti \& Lazdunski (1975) demonstrated that media with high osmotic strength, such as $12 \%$ sucrose, caused a fourfold decrease in the intracellular cAMP level in $E$. coli, and Brownlie et al. (1985) found that a high $\mathrm{NaCl}$ concentration in the medium inhibited adenylate cyclase in Bordetella pertussis. Thus it seems possible that high osmotic strength media lower the intracellular levels of cAMP in Flexibacter Inp strains, resulting in the observed increase in PUFA content. However, it is not clear whether the effect of cAMP on Inp2 and Inp3 was involved in facilitating the transcription of genes encoding for proteins, as has been reported for other organisms (Buettner et al., 1973; Botsford, 1981; Roy et al., 1988), or in the activation of a cAMP-dependent protein kinase. Although protein kinases have been thought to be absent in prokaryotes (Dadssi \& Cozzone, 1985), some exceptions have been found (Muller et al., 1985; Saha et al., 1988). More recently, Kinney et al. (1990) demonstrated regulation of phospholipid biosynthesis by a cAMP kinase in $S$. cerevisiae.

The present study has demonstrated that PUFA synthesis is restored in the normally PUFA-deficient Flexibacter strain Inp3 by increasing the osmotic strength in the medium either with ionic solutes such as $\mathrm{NaCl}$ or non-ionic ones such as sucrose. Nevertheless, it is clear from the data that $\mathrm{NaCl}$ and sucrose are more effective in increasing the proportion of PUFAs than was $\mathrm{KCl}$. However, whilst sea-water medium containing

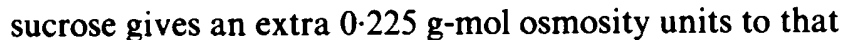
of the sea water $(0.473 \mathrm{~g}-\mathrm{mol}), 30 \mathrm{~g} \mathrm{l}^{-1}$ of both $\mathrm{NaCl}$ and $\mathrm{KCl}$ gives $0.523 \mathrm{~g}$-mol and $0.404 \mathrm{~g}$-mol osmosity units respectively (Weast, 1987). Hence it can be concluded that osmotic strength is not the only factor controlling PUFA biosynthesis.

Addition of the uncoupler DNP has been shown to raise the cAMP level in the yeast Saccharomyces cerevisiae (Thevelein et al., 1987). Fatty acid analysis of protonophore-resistant bacteria has revealed variation between species. Thus, whilst unsaturated fatty acids decreased in Bacillus subtilis (Krulwich et al., 1987), they increased in E. coli (Herring et al., 1985). Furthermore, Kogure \& Tokuda (1986) showed that the growth of marine bacteria can depend on either the proton- or sodium-motive force. On this basis, it may be suggested that the inhibition by DNP of PUFA synthesis in Flexibacter Inp3, as seen in the present study, was caused by an increase in cellular cAMP, which in turn was regulated by changes in membrane electrochemical potential.

\section{References}

Alaniz, M. J. T., Gomez Dumm, I. N. T. \& Brenner, R. R. (1976). The action of insulin and dibutyryl cyclic AMP on the biosynthesis of polyunsaturated acids of the $\gamma$-linolenic acid family in HTC cells. Molecular and Cellular Biochemistry 12, 3-8.

BLIGH, E. G. \& Dyer, W. J. (1959). A rapid method of total lipid extraction and purification. Canadian Journal of Biochemistry and Physiology 37, 911-917.

Bloomfield, D. K. \& BloCh, K. (1960). The formation of 9unsaturated fatty acids. Journal of Biological Chemistry 235, 337-345.

Botsford, J. L. (1981). Cyclic nucleotides in prokaryotes. Microbiological Reviews 45, 620-642.

Brownlie, R. M., Parton, R. \& Coote, J. G. (1985). The effect of growth conditions on adenylate cyclase activity and virulencerelated properties of Bordetella pertussis. Journal of General Microbiology 131, 17-25.

Buettner, M. J., Spitz, E. \& Rickenberg, H. V. (1973). Cyclic adenosine $3^{\prime}, 5^{\prime}$-monophosphate in Escherichia coli. Journal of Bacteriology 114, 1068-1073.

BUTTKE, T. M. \& INGRAM, L. O. (1978). Inhibition of unsaturated fatty acid synthesis in Escherichia coli by the antibiotic cerulenin. Biochemistry 17, 5282-5286.

D'Agnolo, G., Rosenfeld, I. S., Awaya, J. M., Omura, S. \& VAGELOS, R. (1973). Inhibition of fatty acid synthesis by the antibiotic cerulenin. Specific inactivation of $\beta$-ketoacyl carrier protein synthetase. Biochimica et Biophysica Acta 326, 155-166.

Dallas, S. W., Tseng, Y. \& Dobrogosz, W. J. (1976). Regulation of membrane functions and fatty acid composition in Escherichia coli by cyclic AMP receptor protein. Archives of Biochemistry and Biophysics 175, 295-302.

Dadssi, M. \& Cozzone, A. J. (1985). Cyclic AMP independence of Escherichia coli protein phosphorylation. FEBS Letters 186, 187-190.

Delong, E. F. \& Yayanos, A. A. (1986). Biochemical function and ecological significance of novel bacteria lipids in deep-sea prokaryotes. Applied and Environmental Microbiology 51, 730-737.

ERWIN, J. \& BLOCH, K. (1964). Biosynthesis of unsaturated fatty acids in microorganisms. Science 143, 1006-1012.

Fulco, A. J. (1970). The biosynthesis of unsaturated fatty acids by bacilli. II. Temperature dependent biosynthesis of polyunsaturated fatty acids. Journal of Biological Chemistry 245, 2985-2990.

Fulco, A. J. (1983). Fatty acid metabolism in bacteria. Progress in Lipid Research 22, 133-160.

GolDFINE, H. \& BLOCH, K. (1961). On the origin of unsaturated fatty acids in clostridia. Journal of Biological Chemistry 236, 2591-2601.

HaRwOOD, J. L. \& Russell, N. J. (1984). Lipids in Plants and Microbes. London: George Allen \& Unwin.

Herring, F. G., Krisman, A., Sedgwick, S. E. \& Bragg, P. D. (1985). Electron resonance of lipid fluidity changes in membranes of an uncoupler resistant mutant of Escherichia coli. Biochemica et Biophysica Acta 819, 231-240.

INTRIAGO, P. \& FlOODGATE, G. D. (1991). Fatty acid composition of the estuarine Flexibacter sp. strain Inp: effect of salinity, temperature and carbon source for growth. Journal of General Microbiology 137, 1503-1509.

Kinney, A. J., Bae-ee, M., Panghaal, S. S., Kelley, M. J., Gaynor, P. M. \& Carman, G. M. (1990). Regulation of phospholipid biosynthesis in Saccharomyces cerevisiae by cyclic AMP-dependent protein kinase. Journal of Bacteriology 172, 1133-1136.

KOGURE, K. \& TOKUDA, H. (1986). Membrane bioenergetics of halophilic marine bacteria. In Perspectives in Microbial Ecology, 4th International Symposium on Microbial Ecology, pp. 231-237. Edited by F. Megusar \& M. Gantar. Ljubljana: Slovene Society for Microbiology. 
Krulwich, T. A., Clejan, S., Falk, L. H. \& Guffanti, A. A. (1987) Incorporation of specific exogenous fatty acids into membrane lipids modulates protonophore resistance in Bacillus subtilis. Journal of Bacteriology 169, 4479-4485.

LAM, S. \& GRUSHKa, E. (1985). Applications of phenacyl derivatives for the determination of fatty acids by HPLC. Separation and Purification Methods 14, 67-96.

LARSEN, A. D. \& SYPHeRD, P. S. (1974). Cyclic adenosine 3',5'monophosphate and morphogenesis in Mucor racemosus. Journal of Bacteriology 117, 432-438.

MUller, R., SChMid, W. E. \& Stier, A. (1985). The site of cyclic AMP-dependent protein kinase catalysed phosphorylation of cytochrome P450-LM2. FEBS Letters 187, 21-24.

Pauli, G., Ehring, R. \& Overath, P. (1974). Fatty acid degradation in Escherichia coli: requirement of cyclic adenosine monophosphate and cyclic adenosine monophosphate receptor protein for enzyme synthesis. Journal of Bacteriology 117, 1178-1183.

Piovanti, M. \& Lazdunski, C. (1975). Different cyclic adenosine 3',5'monophosphate requirements for induction of $\beta$-galactosidase and tryptophanase. Effect of osmotic pressure on intracellular cyclic adenosine $3^{\prime}, 5^{\prime}$-monophosphate concentrations. Biochemistry 14, 1821-1825.

REICHENBACH, H. \& DwORKIN, M. (1981). Introduction to the gliding bacteria. In The Prokaryotes, vol. 1, pp. 315-327. Edited by M. P. Starr, H. Stolp, H. G. Truper, A. Balows \& H. G. Schlegel. Berlin: Springer Verlag.

Roy, A., Glaser, P. \& Danchin, A. (1988). Aspects of the regulation of adenylate cyclase synthesis in Escherichia coli K12. Journal of General Microbiology 134, 359-367.

RUSSELL, N. J. (1978). The positional specifity of a desaturase in the psychrophilic bacterium Microccocus cryophilus. Biochimica et Biophysica Acta 531, 179-185.

Saha, A., Dowling, J. N., Mukhopadhyay, N. K. \& Glew, R. H. (1988). Demonstration of two protein kinases in extracts of Legionella micdadei. Journal of General Microbiology 134, 1275-1281.

SCHEUERBRAND, G. \& BLOCH, K. (1962). Unsaturated fatty acids in microorganisms. Journal of Biological Chemistry 237, 2064-2068.

SCHWEIZER, E. (1989). Biosynthesis of fatty acids and related compounds. In Microbial Lipids, vol. 2, pp. 3-50. Edited by C. Ratledge \& S. G. Wilkinson. London: Academic Press.

Thevelein, J. M., Beullens, M., Honshoven, F., Hoebeeck, G., Detremerie, K., Den Hollander, J. A. \& Jans, A. W. (1987). Regulation of the cAMP level in the yeast Saccharomyces cerevisiae: intracellular $\mathrm{pH}$ and the effect of membrane depolarizing compounds. Journal of General Microbiology 133, 2191-2196.

WadA, M., Fukunaga, N. \& SAaki, M. (1989). Mechanism of biosynthesis of unsaturated fatty acids in Pseudomonas sp. strain E-3, a psychrotrophic bacterium. Journal of Bacteriology 171, 4267-4271.

Weast, R. C. (1987). Handbook of Chemistry and Physics, 67th edn. Boca Raton, Florida: CRC Press.

Wirsen, C. O., Jannasch, H. W., Wateham, S. G. \& Canuel, E. A. (1987). Membrane lipids of psychrophilic and barophilic deep-sea bacteria. Current Microbiology 14, 319-322.

WoOD, R. \& LEE, T. (1983). High performance liquid chromatography of fatty acids: quantitative analysis of saturated monoeic, polyonic and geometrical isomers. Journal of Chromatography 254, 237-246.

Yazawa, K., Araki, K., Watanabe, K., Ishikawa, C., Inoue, A., Kondo, K., Watabe, S. \& Hashimoto, K. (1988). Eicosapentanoic acid productivity of the bacteria isolated from fish intestines. Nippon Suisan Gakkaishi 54, 1835-1838. 